\title{
Scale effect on runoff and soil loss control using rice straw mulch under laboratory conditions
}

\author{
S. H. R. Sadeghi ${ }^{1}$, L. Gholami ${ }^{1}{ }^{*}$, E. Sharifi ${ }^{1}$, A. Khaledi Darvishan ${ }^{1}$, and M. Homaee ${ }^{2}$ \\ ${ }^{1}$ Department of Watershed Management Engineering, Faculty of Natural Resources, Tarbiat Modares University, \\ P.O. Box 46417-76489, Noor, Iran \\ ${ }^{2}$ Department of Soil Science, Faculty of Agriculture, Tarbiat Modares University, Tehran, Iran \\ *now at: Department of Rangeland and Watershed Management, Faculty of Natural Resources, Sari Agricultural Sciences and \\ Natural Resources University, Sari, Iran \\ Correspondence to: S. H. R. Sadeghi (sadeghi@modares.ac.ir)
}

Received: 10 September 2014 - Published in Solid Earth Discuss.: 9 October 2014

Revised: 12 November 2014 - Accepted: 27 November 2014 - Published: 5 January 2015

\begin{abstract}
Amendments can control the runoff and soil loss by protecting the soil surface. However, scale effects on runoff and soil loss control have not been considered yet. The present study has been formulated to determine the efficiency of two plot sizes of 6 and $0.25 \mathrm{~m}^{2}$ covered by $0.5 \mathrm{~kg} \mathrm{~m}^{-2}$ of straw mulch with regard to changing the time to runoff, runoff coefficient, sediment concentration and soil loss under laboratory conditions. The study used a sandy-loam soil taken from summer rangeland, Alborz Mountains, northern Iran, and was conducted under simulated rainfall intensities of 50 and $90 \mathrm{~mm} \mathrm{~h}^{-1}$ and in three replicates. The results of the study showed that the straw mulch had a more significant effect on reducing the runoff coefficient, sediment concentration and soil loss on a $0.25 \mathrm{~m}^{2}$ plot scale. The maximum effectiveness in time to runoff for both the scales was observed at a rainfall intensity of $90 \mathrm{~mm} \mathrm{~h}^{-1}$. The maximum increasing and decreasing rates in time to runoff and runoff coefficient were observed at a rainfall intensity of $90 \mathrm{~mm} \mathrm{~h}^{-1}$, with 367.92 and $96.71 \%$ for the $0.25 \mathrm{~m}^{2}$ plot and 110.10 and $15.08 \%$ for the $6 \mathrm{~m}^{2}$ plot. The maximum reduction in the runoff coefficient was in the $0.25 \mathrm{~m}^{2}$ plot for the two rainfall intensities of 50 and $90 \mathrm{~mm} \mathrm{~h}^{-1}$, with rates of -89.34 and $-96.71 \%$. The maximum change in soil loss at the intensities of both 50 and $90 \mathrm{~mm} \mathrm{~h}^{-1}$ occurred in the $0.25 \mathrm{~m}^{2}$ plot, with $100 \%$, whereas in the $6 \mathrm{~m}^{2}$ plot, decreasing rates of soil loss for the intensities of both 50 and $90 \mathrm{~mm} \mathrm{~h}^{-1}$ were 46.74 and $63.24 \%$, respectively.
\end{abstract}

\section{Introduction}

The soil erosion rates are accelerated by tillage and low vegetation cover (Cerdà et al., 2009 and 2010). Population increase and a growing demand for agricultural products (Prokop and Poręba, 2012; Zhao et al., 2013) and intensive dry land (Biro et al., 2013) has generated changes in land use and resulted in erosion and land degradation. There are various methods for soil conservation, but biological methods in bare and degraded slopes need a long time to become established (Adekalu et al., 2007; Smets et al., 2008a). In this context, various natural and organic mulches viz. crop residues, leaf litter, woodchips, bark chips, biological geotextiles, gravel and crushed stones (Ruy, 2006; Smets et al., 2008a; Ruiz-Sinoga et al., 2010) have been applied for soil conservation. Mulches have extraordinary potential in soil erosion control (Morgan, 1986) and runoff reduction (Poesen and Lavee, 1991). However, the establishment of degraded areas and bare slopes by vegetation cover takes a long time (Adekalu et al., 2007; Smets et al., 2008a). The effect of mulches depends on many factors, including raindrop erosivity, soil condition, steepness and length of the slope, and the mulch rate and type (Amimoto, 1981; Cogo et al., 1984; Poesen and Lavee, 1991; Morgan, 1995; Auerswald et al., 2003; Adekalu et al., 2007; Kukal and Sarkar, 2010; Jordán et al., 2010; Choi et al., 2012; Gholami et al., 2013). Straw mulch as an organic amendment reduces soil erosion but also recovers the main soil properties lost due to agriculture 
(García-Orenes et al., 2009, 2010); this is also done by other materials (Giménez Morera et al., 2010).

Although there are a lot of studies about soil amendments as a means of soil conservation, e.g., Fernández et al. (2012), Jiménez et al. (2012), García-Moreno et al. (2013), Robichaud et al. (2013), Lieskovský and Kenderessy (2014) and Martins et al. (2014), the effects of the study scale on the effectiveness of various mulch covers have rarely been considered. There are a few studies about the spatial-scale variations in mulches on runoff and soil loss. Poesen et al. (1994) reviewed the effects of rock fragments on soil erosion and stated that the spatial scale has an important impact on the soil erosion. They showed that, on the microplot scale $\left(4 \mathrm{~mm}^{2}\right.$ to $1 \mathrm{~m}^{2}$ ), sediment yield reached a maximum value with $0 \%$ rock fragment cover and reached a minimum value with $100 \%$ rock fragment cover. On the mesoplot scale (i.e., interrill areas), negative, positive as well as convex upward relationships with cover percentages have been observed, depending on the fine-earth structure, on the vertical position in the topsoil, on the size of rock fragments and on the surface slope. Finally, on the macroplot scale (i.e., interrill and rill areas; 10-10000 $\mathrm{m}^{2}$ ), sediment yield decreased exponentially with rock fragment cover. Cerdan et al. (2002) investigated the scale effect (plot to catchment) on runoff in agricultural areas of Normandy, France. Three databases $-450 \mathrm{~m}^{2}$ plots, a 90 ha catchment and an 1100 ha catchment - were selected to collect runoff data. Between the three scales, a significant decrease in the runoff coefficient was observed as the area increased. Mingguo et al. (2007) also studied the effect of vegetation on the runoff-sediment-yield relationship on different spatial scales (plot to watershed) in hilly areas of the Loess Plateau, northern China, and found that vegetation could reduce runoff and soil loss on both scales but that, on a plot scale, the reduction rate of sediment was more than the runoff. Smets et al. (2008a) reviewed the impact of plot length on the effectiveness of different soil surface covers in reducing runoff and soil loss. The results indicated that, for plot lengths $<11 \mathrm{~m}$, there was a large variation in the runoff and erosion-reducing effectiveness of each soil cover, depending on various factors. Smets et al. (2008b) also examined the spatial-scale effects on the effectiveness of organic mulches in reducing soil erosion in field and laboratory experiments (plot length ranges between 0.1 and $30.5 \mathrm{~m}$ ). Results verified the effectiveness of mulches in reducing soil erosion by water on various scales. In addition, they showed a positive linear relation between the erosion-reducing effectiveness of an organic mulch cover and plot length. In short plots, the response of a soil surface cover to runoff and soil loss was immediately observed. Nevertheless, on longer plots, the runoff and soil loss response could be compensated for due to the longer plot length. Fernández et al. (2012) studied the seeding and the mulching and seeding effects on post-fire runoff and soil erosion in Galicia (NW Spain), with a rainfall rate of $67 \mathrm{~mm} \mathrm{~h}^{-1}$ at plot scale. They showed that the conserved treatments did not significantly increase soil cover or affect runoff, but soil losses were low in all cases. García-Orenes et al. (2012) demonstrated that the use of a cover (plants or straw) contributes to increases in soil quality and reduces the risk of erosion. Liu et al. (2012) evaluated the effects of rice straw mulch and plastic film mulching at plot scale over 2 years in the Xiaofuling watershed in the Danjiangkou Reservoir area, China. The straw mulch treatment significantly decreased the sediment yield from 18 to $22 \%$. The results showed that the straw mulch was beneficial for controlling runoff and sediment.

Scrutinizing the available literature showed that, although there are lots of references to using straw as mulch for runoff and soil erosion control, there is no literature that reports the effectiveness of straw mulch on various plot scales. The present study was therefore planned to determine the efficiency of two plot sizes covered by straw mulch in changing the important runoff and soil loss components under laboratory conditions.

\section{Materials and methods}

The laboratory experiments were conducted by using two sets of $6 \times 1 \mathrm{~m}$ and $0.5 \times 0.5 \mathrm{~m}$ plots installed in the rainfall simulator laboratory, Faculty of Natural Resources of Tarbiat Modares University (TMU), located in Noor, Mazandaran Province, northern Iran. The experiments were carried out to study the effect of rice straw mulch on runoff and soil loss processes by using simulated rainfall at an intensity of 50 and $90 \mathrm{~mm} \mathrm{~h}^{-1}$ and in three replicates (there were 24 experiments in total: 12 experiments for a rainfall intensity of $50 \mathrm{~mm} \mathrm{~h}^{-1}$, of which 6 experiments were control treatments and 6 experiments were conservation treatments, and another 12 treatments for a rainfall intensity of $90 \mathrm{~mm} \mathrm{~h}^{-1}$, of which $6 \mathrm{ex}-$ periments were control treatments and 6 experiments were conservation treatments). The entire number of eight treatments in three replicates was formulated as a factorial design as shown in the following: 2 plot sizes $\left(0.25\right.$ and $\left.6 \mathrm{~m}^{2}\right) \times 2$ rainfall intensities (50 and $\left.90 \mathrm{~mm} \mathrm{~h}^{-1}\right) \times 2$ treatments (control and straw mulch) $=8$ treatments; 3 replicates $=$ total of 24 rainfall simulations

The rainfall simulator consists of a $4000 \mathrm{~L}$ water tank and 27 precalibrated nozzles in three parallel lines designed to simulate raindrops of an average size of $1.3 \mathrm{~mm}$. The drops fall from a height of between 4 and $6 \mathrm{~m}$ at the upper and lower parts of the plot, respectively, reaching a speed of $7 \mathrm{~m} \mathrm{~s}^{-1}$ (Duiker et al., 2001).

A sandy-loam (14\% clay, $24 \%$ silt and $62 \%$ sand) topsoil was collected from a depth of 0-20 cm (Kukal and Sarkar, 2010) in the Alborz Mountains, northern Iran. The soil was transported to the lab and air-dried to the optimum moisture content to maintain the relative stability of soil aggregates and decrease the breakdown of the aggregates in the sieving process (Khaledi Darvishan et al., 2013). The coarse rock fragments and plant residues were removed from the soil 

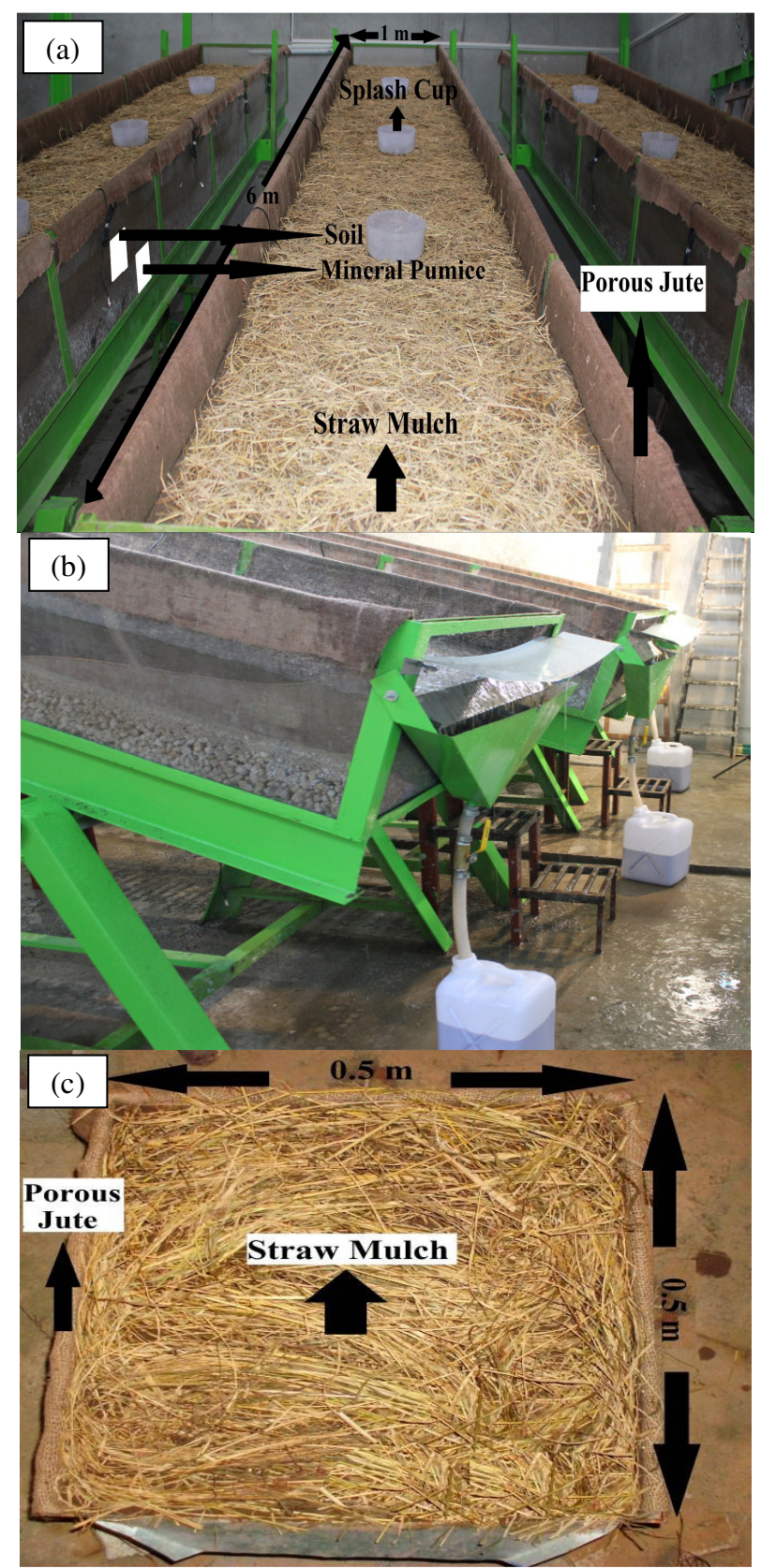

Figure 1. A general view of the treated plots of $6 \mathrm{~m}^{2}$ (a), the runoff collection system at a $6 \mathrm{~m}^{2}$ plot outlet (b) and $0.25 \mathrm{~m}^{2}$ (c) with rice straw mulch under lab conditions.

through passing it through an $8 \mathrm{~mm}$ sieve to obtain maximum homogeneity in the soil profile (Hawke et al., 2006). The $\mathrm{pH}$, electrical conductivity (EC) and organic matter of the experi-

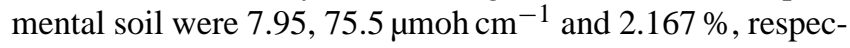
tively.
Three layers of mineral pumice grains with different sizes and a total thickness of $15 \mathrm{~cm}$ were used as a filter layer and placed at the bottom of the plots in order to simulate natural drainage conditions and decreasing plot weight (Defersha et al., 2011). A $15 \mathrm{~cm}$ thick soil layer was then placed on the top and separated from the mineral pumice by a sheet of porous jute (Defersha et al., 2011). The soil was ultimately compacted by a small PVC roller (a handmade roller filled with cement and sand) to achieve the bulk density of $1.38 \mathrm{~g} \mathrm{~cm}^{-3}$, almost equal to that measured for the soil under natural conditions (Romkens et al., 2001; Saedghi et al., 2010; Gholami et al., 2013). Each experiment was also covered using new soil and straw mulch (Adekalu et al., 2007). The rainfall intensities of 50 and $90 \mathrm{~mm} \mathrm{~h}^{-1}$ with a duration of $15 \mathrm{~min}$ were considered to correspond to climatological conditions at the location of origin of the soil; these conditions were obtained through intensity-duration-frequency (IDF) curve analysis for data collected in the nearest synoptic station (Kojour; longitude $51^{\circ} 44^{\prime}$, latitude $36^{\circ} 23^{\prime}$; height $1550 \mathrm{~m}$ ) with a return period of less than 20 years.

Finally, the air-dried rice straw mulch was spread over the soil surface 5 days before treatments, with a cover, thickness and dry weight of about $90 \%$ (Das and Agrawal, 2002; Adekalu et al., 2007; Kukal and Sarkar, 2010), $\sim 8 \mathrm{~cm}$ and $0.5 \mathrm{~kg} \mathrm{~m}^{-2}$, respectively. A general view of the experimental plots and setups is shown in Fig. 1. The control plots subjected to the study rain storms were monitored under identical lab conditions on bare soils and just before applying the straw mulch.

The time to runoff, runoff coefficient and soil loss were measured at the outlet of each plot for control (before mulching) and treated plots (after mulching) at intervals of 2 min (Ruiz-Sinoga et al., 2010). To establish the runoff and sediment fluxes in all experiments, the 2 min interval was considered appropriate because of the short whole duration of the experiments $(15 \mathrm{~min})$. The amount of soil loss was then measured using a decantation procedure; the soil was oven-dried at $105^{\circ} \mathrm{C}$ for $24 \mathrm{~h}$ and weighed by means of highprecision scales (Kukal and Sarkar, 2011; Gholami et al., 2013).

The general linear model (GLM) using the SPSS 17 software (SPSS Inc. Released 2009) was applied to statistically analyze the main (individual) and interaction effects of spatial scale (plot size), conservation treatments and rainfall intensity on the quantitative characteristics of runoff, sediment concentration and soil loss. The necessary prerequisites were also fulfilled before applying the GLM.

\section{Results and discussion}

The amount of time to runoff and the runoff coefficient before and after the conservation treatment in each plot output and each scale are shown in Table 1. The percentage of 
Table 1. Time to runoff and coefficient before and after conservation treatment on study scales.

\begin{tabular}{|c|c|c|c|c|c|c|}
\hline \multirow[t]{2}{*}{$\begin{array}{l}\text { Plot area } \\
\left(\mathrm{m}^{2}\right)\end{array}$} & \multirow{2}{*}{$\begin{array}{l}\text { Rainfall } \\
\text { intensity } \\
\left(\mathrm{mm} \mathrm{h}^{-1}\right)\end{array}$} & \multirow{2}{*}{$\begin{array}{l}\text { Kinetic energy } \\
\text { of rainfall } \\
\left(\mathrm{j} \mathrm{m}^{-2}\right)\end{array}$} & \multicolumn{2}{|c|}{$\begin{array}{l}\text { Time to runoff (s) } \\
\text { (s) }\end{array}$} & \multicolumn{2}{|c|}{$\begin{array}{c}\text { Runoff coefficient }(\%) \\
(\%)\end{array}$} \\
\hline & & & Control & Treated & Control & Treated \\
\hline \multirow[t]{8}{*}{0.25} & 50 & 23.41 & 420.00 & 480.00 & 24.56 & 2.03 \\
\hline & & & 609.6 & 368.4 & 19.60 & 2.94 \\
\hline & & & 432.00 & 372.00 & 23.86 & 2.07 \\
\hline & & SD & 106.17 & 63.42 & 2.68 & 0.51 \\
\hline & 90 & 24.10 & 69.00 & 480.00 & 34.18 & 1.30 \\
\hline & & & 120.00 & 564.00 & 49.56 & 1.18 \\
\hline & & & 126.00 & 300.00 & 37.91 & 1.39 \\
\hline & & SD & 31.32 & 134.88 & 8.02 & 0.11 \\
\hline \multirow[t]{8}{*}{6} & 50 & 23.22 & 38.51 & 72.52 & 69.35 & 60.20 \\
\hline & & & 30.27 & 68.11 & 68.45 & 62.95 \\
\hline & & & 34.34 & 70.44 & 69.48 & 62.48 \\
\hline & & SD & 4.12 & 2.21 & 0.56 & 1.47 \\
\hline & 90 & 21.15 & 23.15 & 56.11 & 79.42 & 66.85 \\
\hline & & & 30.32 & 52.27 & 78.32 & 72.18 \\
\hline & & & 26.70 & 57.28 & 77.65 & 60.90 \\
\hline & & SD & 3.59 & 2.45 & 0.90 & 5.64 \\
\hline
\end{tabular}

Table 2. Changes (\%) in time to runoff and coefficient in plots treated with rice straw mulch.

\begin{tabular}{lccc}
\hline Plot area $\left(\mathrm{m}^{2}\right)$ & Variable & \multicolumn{2}{c}{ Rainfall intensity $\left(\mathrm{mm} \mathrm{h}^{-1}\right)$} \\
& & 50 & 90 \\
\hline 0.25 & Time to runoff & -13.06 & +367.92 \\
& Coefficient & -89.34 & -96.71 \\
\hline 6 & Time to runoff & +106.15 & +110.10 \\
& Coefficient & -10.43 & -15.08 \\
\hline
\end{tabular}

changes in study variables in treated plots and in comparison with control plots has been summarized in Table 2 .

Tables 1 and 2 showed that the straw mulch increased time to runoff compared to untreated plots except at a rainfall intensity of $50 \mathrm{~mm} \mathrm{~h}^{-1}$ for the $0.25 \mathrm{~m}^{2}$ plot; it also decreased the runoff coefficient on both the scales. This might be due to the water-storing effects of straw and also an increasing ponding time on the plot surface. This finding is in line with that reported by Poesen and Lavee (1991), Mingguo et al. (2007) and Smets et al. (2008a, b). However, the maximum change in effectiveness in time to runoff, for the two scales, could be found at a rainfall intensity of $90 \mathrm{~mm} \mathrm{~h}^{-1}$.
These effects were more serious in the $0.25 \mathrm{~m}^{2}$ plot, with a rate of $+367.92 \%$, while the $6 \mathrm{~m}^{2}$ plot, compared to the $0.25 \mathrm{~m}^{2}$ plot, could reduce the time to runoff at a rainfall intensity of $50 \mathrm{~mm} \mathrm{~h}^{-1}$, with a rate of $+106.15 \%$. Figures 2 and 3 also show the average rates of time to runoff and the coefficient on both scales.

Scrutinizing Table 2 and Figs. 2 and 3 also verified the varying effect of straw mulch on the runoff coefficient, which ranged from -10.43 to $-96.71 \%$ on the two scales. The minimum and the maximum effects also occurred at rainfall intensities of $50 \mathrm{~mm} \mathrm{~h}^{-1}$ in the $6 \mathrm{~m}^{2}$ plot, with a rate of $-10.43 \%$, and of $90 \mathrm{~mm} \mathrm{~h}^{-1}$ in the $0.25 \mathrm{~m}^{2}$ plot, with a rate of $96.71 \% \mathrm{~mm} \mathrm{~h}^{-1}$. The $0.25 \mathrm{~m}^{2}$ plot had the maximum reduction in runoff coefficient when rainfall intensities were 50 and $90 \mathrm{~mm} \mathrm{~h}^{-1}$. These results showed that the $0.25 \mathrm{~m}^{2}$ plot had the maximum impact on decreasing the runoff coefficient and increasing time to runoff, except in the case of a rainfall intensity of $50 \mathrm{~mm} \mathrm{~h}^{-1}$. It verified that the straw mulch pieces could store more runoff, leading to more infiltration, as already reported by Poesen and Lavee (1991), Choi et al. (2012) and Liu et al. (2012). The results showed that there was large variation in the runoff coefficient (Smets et al., 2008a) and time to runoff on the $0.25 \mathrm{~m}^{2}$ plots compared to those recorded for the $6 \mathrm{~m}^{2}$ plots at variousrainfallintensities. 
Table 3. Sediment concentration and soil loss measured at the outlet of the study plots before and after applying conservation treatment.

\begin{tabular}{|c|c|c|c|c|c|}
\hline \multirow{2}{*}{$\begin{array}{l}\text { Plot area } \\
\qquad\left(\mathrm{m}^{2}\right)\end{array}$} & \multirow{2}{*}{$\begin{array}{l}\text { Rainfall intensity } \\
\qquad\left(\mathrm{mm} \mathrm{h}^{-1}\right)\end{array}$} & \multicolumn{2}{|c|}{ Sediment concentration $\left(\mathrm{g} \mathrm{L}^{-1}\right)$} & \multicolumn{2}{|c|}{ Soil loss (g) } \\
\hline & & Control & Treated & Control & Treated \\
\hline \multirow[t]{8}{*}{0.25} & 50 & 2.04 & 0.00 & 1.61 & 0.00 \\
\hline & & 1.13 & 0.00 & 0.98 & 0.00 \\
\hline & & 1.88 & 0.00 & 1.54 & 0.00 \\
\hline & SD & 0.49 & 0.00 & 0.35 & 0.00 \\
\hline & 90 & 2.69 & 0.00 & 3.78 & 0.00 \\
\hline & & 1.56 & 0.00 & 3.42 & 0.00 \\
\hline & & 2.00 & 0.00 & 3.27 & 0.00 \\
\hline & SD & 0.57 & 0.00 & 0.26 & 0.00 \\
\hline \multirow[t]{8}{*}{6} & 50 & 6.13 & 3.87 & 226.27 & 131.38 \\
\hline & & 7.43 & 3.69 & 266.64 & 128.94 \\
\hline & & 8.27 & 4.70 & 302.82 & 161.62 \\
\hline & SD & 1.08 & 0.54 & 38.29 & 18.20 \\
\hline & 90 & 10.28 & 4.39 & 756.69 & 286.37 \\
\hline & & 10.71 & 4.47 & 787.94 & 315.10 \\
\hline & & 10.15 & 4.01 & 738.20 & 239.42 \\
\hline & SD & 0.29 & 0.25 & 25.14 & 38.20 \\
\hline
\end{tabular}

Table 4. Reduction rates (\%) in average sediment concentration and soil loss in plots treated with rice straw mulch.

\begin{tabular}{lccc}
\hline Plot area $\left(\mathrm{m}^{2}\right)$ & Variable & \multicolumn{2}{c}{ Rainfall intensity $\left(\mathrm{mmh}^{-1}\right)$} \\
& & 50 & 90 \\
\hline 0.25 & Sediment concentration & -100 & -100 \\
& Soil loss & -100 & -100 \\
\hline 6 & Sediment concentration & -43.47 & -58.69 \\
& Soil loss & -46.74 & -63.24 \\
\hline
\end{tabular}

In this study the effectiveness of mulch in reducing runoff was influenced by the plot size. Thus, the runoff amount increased with increasing plot size, while Poesen et al. (1994), Cerdan et al. (2002) and Smets et al. (2008a, b) showed that the runoff amount decreased with increasing plot size. The differences between mulch type, application manner and density as well as soil type and rainfall intensity could be supposed as potential reasons behind the disagreement. However, according to McGregor et al. (1988), plot border effects on runoff rates were much more important in small plots compared to large ones.

Tables 3 and 4 showed that the conservation treatment essentially reduced soil loss, which is consistent with Poesen and Lavee (1991), Fernández et al. (2012), García-Orenes et al. (2014) and Fernández and Vega (2014). Sediment concentration also decreased in treated plots, as also reported by Poesen and Lavee (1991) and Smets et al. (2008a and b). This indicated that the flow was not powerful enough to detach particles. A similar finding has been reported by Poesen and Lavee (1991).

The sediment concentration and soil loss amounts before and after the conservation treatment on each scale are shown in Table 3. The relative effectiveness of straw mulch on sediment concentration and soil loss for the two scales is also summarized in Table 4. Figures 4 and 5, respectively, show the average rates of sediment concentration and soil loss in the two study plots.

Table 4 and Figs. 4 and 5 also show that the amounts of sediment concentration on the two study scales changed from -43.47 to $-100 \%$. The maximum change occurred in the $0.25 \mathrm{~m}^{2}$ plot at the intensities of both 50 and $90 \mathrm{~mm} \mathrm{~h}^{-1}$. Thus, soil loss was found to be negligible after mulching in a small plot of $0.25 \mathrm{~m}^{2}$ (Poesen et al., 1994). The results also showed that soil loss was reduced in the 0.25 and $6 \mathrm{~m}^{2}$ plots; moreover, the variation ranged from -58.69 to $-100 \%$. Poesen et al. (1994) found that soil loss was reduced by $100 \%$ in small plots of $1 \mathrm{~m}^{2}$ with a cover of $100 \%$. It was also 
Table 5. Results of GLM test for plot size and conservation treatment effects on the quantitative characteristics of runoff and soil loss.

\begin{tabular}{|c|c|c|c|c|c|c|}
\hline Source & Dependent variable & Type III sum of squares & $\mathrm{d} f$ & Mean square & $F$ & Significant level \\
\hline \multirow[t]{4}{*}{ Plot } & Time to runoff (s) & 595564.22 & 1 & 595564.22 & 40.92 & 0.00 \\
\hline & Runoff coefficient $(\%)$ & 16413.83 & 1 & 16413.83 & 381.42 & 0.00 \\
\hline & Sediment concentration $\left(\mathrm{gL}^{-1}\right)$ & 185.59 & 1 & 185.59 & 194.67 & 0.00 \\
\hline & Soil loss (g) & 780024.69 & 1 & 780024.69 & 38.46 & 0.00 \\
\hline \multirow[t]{4}{*}{ Treatment } & Time to runoff (s) & 40142.53 & 1 & 40142.53 & 2.76 & 0.11 \\
\hline & Runoff coefficient $(\%)$ & 2317.91 & 1 & 2317.91 & 53.86 & 0.00 \\
\hline & Sediment concentration $\left(\mathrm{gL}^{-1}\right)$ & 63.64 & 1 & 63.64 & 66.75 & 0.00 \\
\hline & Soil loss (g) & 139578.68 & 1 & 139578.68 & 6.88 & 0.02 \\
\hline \multirow[t]{4}{*}{ Plot treatment } & Time to runoff (s) & 14704.47 & 1 & 14704.47 & 1.01 & 0.33 \\
\hline & Runoff coefficient $(\%)$ & 616.72 & 1 & 616.72 & 14.33 & 0.001 \\
\hline & Sediment concentration $\left(\mathrm{gL}^{-1}\right)$ & 11.48 & 1 & 11.48 & 12.04 & 0.002 \\
\hline & Soil loss (g) & 135178.56 & 1 & 135178.56 & 6.67 & 0.02 \\
\hline
\end{tabular}

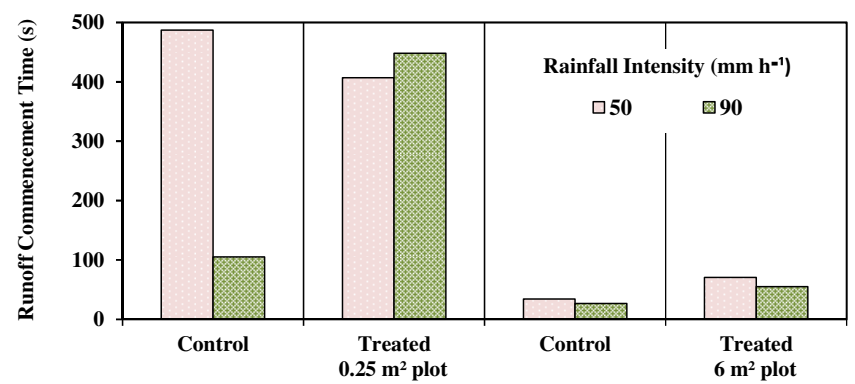

Figure 2. Average time to runoff for the two study scales and the two rainfall intensities.

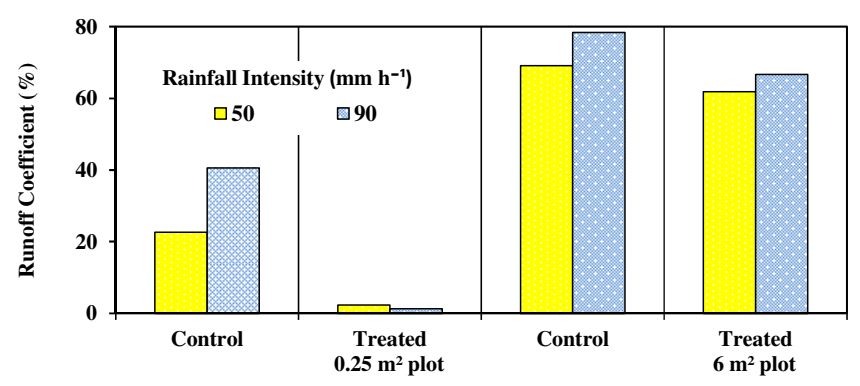

Figure 3. Average runoff coefficient for the two study scales and the two rainfall intensities.

observed that both the study variables achieved the maximum effect in a small plot of $0.25 \mathrm{~m}^{2}$ with regard to decreasing sediment concentration and soil loss. It has also been verified by Mingguo et al. (2007) that soil loss by water erosion in laboratory conditions reduced as plot size decreased. Poesen and Lavee (1994) and Smets et al. (2008a, b) also stated that soil loss by water erosion was influenced by the plot length. They showed that the small plots with mulch cover were significantly less effective in reducing relative soil loss compared to longer plots. By contrast, this study states that the

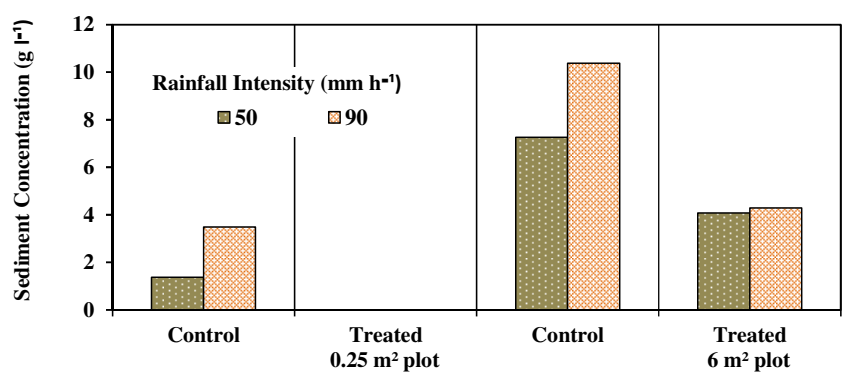

Figure 4. Average sediment concentration for the two study scales and the two rainfall intensities.

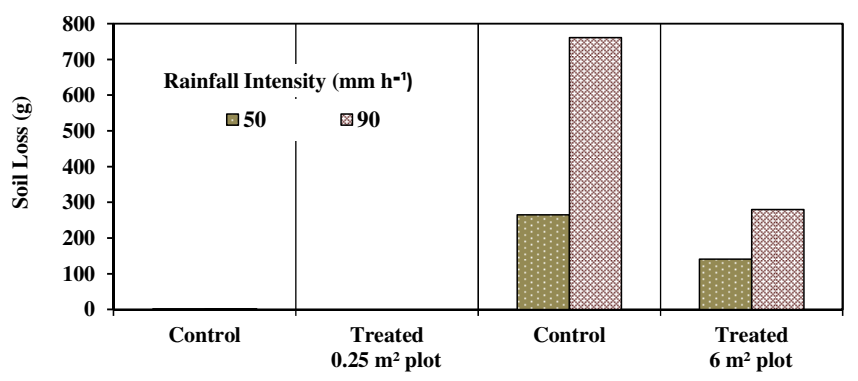

Figure 5. Average soil loss for the two study scales and the two rainfall intensities.

small plot with straw mulch was more effective in reducing runoff and soil loss amounts (Mingguo et al., 2007). Therefore, the effectiveness of mulch cover in reducing runoff and soil loss by water erosion decreased with increasing plot size. These results were not consistent with Poesen et al. (1994) and Smets et al. (2008a, b), whereas they agreed with Mingguo et al. (2007).

Poesen et al. (1994), Cerdan et al. (2002), Boix-Fayos et al. (2006) and Smets et al. (2008a, b) showed that plot length (or spatial scale) can be important in variations in runoff or soil loss rates and in the effectiveness of surface covers. 
These results were found to be important in designing runoff production and erosion plots and modeling runoff and soil loss rates (Smets et al., 2008a).

The results of the statistical analysis based on the GLM is summarized in Table 5. According to Table 5, changing plot size could have a significant effect $(P>0.01)$ on time to runoff and the coefficient, sediment concentration and soil loss. The runoff coefficient $(p=0.00)$, sediment concentration $(p=0.00)$ and soil loss $(p=0.02)$ were significantly influenced by plot size as well as by conservation treatment with rice straw mulch. The interaction effect of plot size and conservation treatment on the runoff coefficient, sediment concentration and soil loss were also significant, with respective $\mathrm{p}$-values of $0.001,0.002$ and 0.02 . However, time to runoff was only influenced by plot size.

\section{Conclusions}

The present study was conducted to study the effects of plot size on runoff and soil loss control. In order to so, two plot scales $\left(0.25\right.$ and $\left.6 \mathrm{~m}^{2}\right)$ were treated with $0.5 \mathrm{~kg} \mathrm{~m}^{-2}$ of rice straw mulch under two rainfall intensities (50 and $90 \mathrm{~mm} \mathrm{~h}^{-1}$ ). The straw mulch increased the time to runoff compared to untreated plots, except at a rainfall intensity of $50 \mathrm{~mm} \mathrm{~h}^{-1}$ for the $0.25 \mathrm{~m}^{2}$ plot, and it also decreased the runoff coefficient on both the scales. The maximum change in effectiveness in the time to runoff, for the two scales, could be found at a rainfall intensity of $90 \mathrm{~mm} \mathrm{~h}^{-1}$. The maximum change in soil loss occurred in the $0.25 \mathrm{~m}^{2}$ plot at the intensities of both 50 and $90 \mathrm{~mm} \mathrm{~h}^{-1}$. The results showed that the $0.25 \mathrm{~m}^{2}$ plot had a better effectiveness in reducing the runoff coefficient, sediment concentration and soil loss. The results of the study clearly proved the different responses of the plots with regard to runoff soil loss components; these results can be practically applied when setting up experimental studies. The results further showed that the plots should mainly be used for comparative studies rather than for those aimed at obtaining accurate data on larger-scale outcomes.

Acknowledgements. The authors would like to thank Professor K. Banasik for his valuable scientific and technical assistance to second and fourth authors at time of their sabbatical programs in Poland led to some new approaches and outcomes. They also appreciate the journal editor, technical assistants and anonymous reviewers for their persistent and accurate endeavors in processing the manuscript.

Edited by: A. Cerdà

\section{References}

Adekalu, K. O., Olorunfemi, I. A., and Osunbitan, J. A.: Grass mulching effect on infiltration, surface runoff and soil loss of three agricultural soils in Nigeria, Bioresour. Technol., 98, 912917, 2007.

Amimoto, P. Y.: Erosion and sediment control handbook, California Department of Conservation Report No. EPA 4 40/3-78-003, 197 pp., 1981.

Auerswald, K., Kainz, M., and Fiener, P.: Soil erosion potential of organic versus conventional farming evaluated by USLE modeling of cropping statistics for agricultural districts in Bavaria, Soil Use Manage., 19, 305-311, 2003.

Biro, K., Pradhan, B., Buchroithner, M., and Makeschin, F.: Land use/land cover change analysis an its impact on soil properties in the Northern part of Gadarif region, Sudan, Land Degradat. Develop., 24, 90-102, 2013.

Boix-Fayos, C., Martínez-Mena, M., Arnau-Rosalén, E., CalvoCases, A., Castillo, V., and Albaladejo, J.: Measuring soil erosion by field plots: understanding the sources of variation, Earth-Sci. Rev., 78, 267-85, 2006.

Cerdà, A., Giménez-Morera, A., and Bodí, M. B.: Soil and water losses from new citrus orchards growing on sloped soils in the western Mediterranean basin, Earth Surf. Proc. Land., 34, 18221830, 2009.

Cerdà, A., Hooke, J., Romero-Diaz, A., Montanarella, L., and Lavee, H.: Soil erosion on Mediterranean Type-Ecosystems, Land Degrad. Develop., 21, 71-74, doi:10.1002/ldr.968, 2010.

Cerdan, O. Y., Le Bissonnais, V., Souchere, P. M., and Lecomte, V.: Sediment concentration in interrill flow: interactions between soil surface conditions, vegetation and rainfall, Earth Surf. Proc. Land. , 27, 193-205, 2002.

Choi, J., Shin, M. H., Yoon, J. S., and Jang, J. R.: Effect of rice straw mulch on runoff and NPS pollution discharges from a vegetable field, International Conference of Agriculture Engineering, July 8-12, Spain, 4 pp., 2012.

Cogo, N. P., Moldenhauer, W. C., and Foster, G. R.: Soil loss reductions from conservation tillage practices, Soil Sci. Soc. Am. J., 48, 368-373, 1984.

Das, D. K. and Agrawal, R. P.: Physical properties of soils, in: Fundamentals of Soil Science, New Delhi, J. Indian Soc. Soil Sci., 283-295, 2002.

Defersha, M. B., Quraishi, S., and Mellese, A. M.: The effect of slope steepness and antecedent moisture content on interrill erosion, runoff and sediment size distribution in the highlands of Ethiopia, Hydrol. Earth Syst. Sci., 15, 2367-2375, 2011.

Duiker, S. W., Flanagan, D. C., and Lal, R.: Erodibility and infiltration characteristics of five major soils of southwest Spain, Catena, 45, 103-121, 2001.

Fernández, C. and Vega, J. A.: Efficacy of bark strands and straw mulching after wildfire in NW Spain: Effects on erosion control and vegetation recovery, Ecol. Engin. , 63, 50-57, 2014.

Fernández, C., Vega, J. A., Jiménez, E., Vieira, D. C. S., Merino, A., Ferreiro, A., and Fonturbel, T.: Seeding and mulching+seeding effects on post-fire runoff, soil erosion and species diversity in Galicia (NW Spain), Land Degrad. Develop., 23, 150-156, 2012.

García-Moreno, J., Gordillo-Rivero, A., Zavala, L. M., Jordán, A., and Pereira, P.: Mulch application in fruit orchards increases the persistence of soil water repellency during a 15 -years period, Soil Till. Res. , 130, 62-68, 2013. 
García-Orenes, F., Cerdà, A., Mataix-Solera, J., Guerrero, C., Bodí, M. B., Arcenegui, V., Zornoza, R., and Sempere, J. G.: Effects of agricultural management on surface soil properties and soilwater losses in eastern Spain, Soil Till. Res., 106, 117-123, 2009.

García-Orenes, F., Guerrero, C., Roldán, A., Mataix-Solera, J., Cerdà, A., Campoy, M., Zornoza, R., Bárcenas, G., and Caravaca, F.: Soil microbial biomass and activity under different agricultural management systems in a semiarid Mediterranean agroecosystem, Soil Till. Res., 109, 110-115, 2010.

García-Orenes, F. Roldán, A., Mataix-Solera, J., Cerdà, A., Campoy, M., Arcenegui, V., and Caravaca, F.: Soil structural stability and erosion rates influenced by agricultural management practices in a semi-arid Mediterranean agro-ecosystem, Soil Use Manag., 28, 571-579, 2012.

Gholami, L., Sadeghi, S. H. R., and Homaee, M.: Straw mulching effect on splash erosion, runoff and sediment yield from eroded plots, Soil Sci. Soc. Am. J., 77, 268-278, 2013.

Giménez Morera, A., Ruiz Sinoga, J. D., and Cerdà, A.: The impact of cotton geotextiles on soil and water losses in Mediterranean rainfed agricultural land, Land Degrad. Develop., 210217, 2010.

Hawke, R. M., Price, A. G., and Bryan, R. B.: The effect of initial soil water content and rainfall intensity on near-surface soil hydrologic conductivity: A laboratory investigation, Catena, 65, 237-246, 2006.

Jordán, A., Zavala, L. M., and Gil, J.: Effects of mulching on soil physical properties and runoff under semi-arid conditions in southern Spain, Catena , 81, 77-85, 2010.

Jordán, A., Zavala, L. M., and Muñoz-Rojas, M.: Mulching, effects on soil physical properties, in: Encyclopedia of Agrophysics, edited by: Gliński, J., Horabik, J., and Lipiec, J., Berlin, Springer, 492-496, 2011.

Khaledi Darvishan, A. V., Sadeghi, S. H. R. Homaee, M., and Arabkhedri, M.: Measuring sheet erosion using synthetic colorcontrast aggregates, Hydrol.Proc., 9 pp., 2013.

Kukal, S. S. and Sarkar, M.: Splash erosion and infiltration in relation to mulching and polyviny alcohol application in semi-arid tropics, Archiv. Agron. Soil Sci., 56, 697-705, 2010.

Kukal, S. S. and Sarkar, M.: Laboratory simulation studies on splash erosion and crusting in relation to surface roughness and raindrop size, J. Ind. Soc. Soil Sci., 59, 87-93, 2011.

Lieskovský, J. and Kenderessy, P.: Modelling the effect of vegetation cover and different tillage practices on soil erosion in vineyards: a case study in Vráble (Slovakia) using watem/sedem, Land Degrad. Develop. , 25, 288-296, 2014.

Liu, Y., Taoa, Y., Wana, K. Y., Zhanga, G. S., Liub, D. B., Xiongb, G. Y., and Chena, F.: Runoff and nutrient losses in citrus orchards on sloping land subjected to different surface mulching practices in the danjiangkou reservoir area of China, Agr. Water Manag., 110, 34-40, 2012.

Mandal, D. and Sharda, V. N.: Appraisal of soil erosion risk in the Eastern Himalayan region of India for soil conservation planning, Land Degrad. Develop., 24, 430-437, 2013.
McGregor, K. C., Bengtson, R. L., and Mutchler, C. K.: Effects of surface straw on interrill runoff and erosion of grenada silt loam, Transact. ASAE, 31, 111-116, 1988.

Mingguo, Z., Qiangguo, C., and Hao, C.: Effect of vegetation on runoff-sediment yield relationship at different spatial scales in hilly areas of the Loess Plateau, North China, Ac. Ecol. Sin., 27, 3572-3581, 2007.

Morgan, R. P. C.: Soil erosion and conservation. Longman Scientific and Technical, Burnt Mile, Harlow, UK, 298 pp., 1986.

Morgan, R. P. C.: Soil erosion and conservation. Longman, Essex, England, 198 pp., 1995.

Prats, S. A., MacDonald, L. H., Monteiro, M., Coelho, C. O. A., and Keizer, J. J.: Effectiveness of forest residue mulching in reducing post-fire runoff and erosion in a pine and a eucalypt plantation in north-central Portugal, Geoderma , 191, 115-124, 2012.

Prats, S. A., Martins, M. A. D. S., Malvar, M. C., Ben-Hur, M., and Keizer, J. J.: Polyacrylamide application versus forest residue mulching for reducing post-fire runoff and soil erosion, Sci. Total Environ., 468/469, 464-474, 2014.

Poesen, J. W. A. and Lavee, H.: Effects of size and incorporation of synthetic mulch on runoff and sediment yield from interrills in a laboratory study with simulated rainfall, Soil Till. Res., 21, 209-223, 1991.

Poesen, J. W., Torri, D., and Bunte, K.: Effects of rock fragments on soil erosion by water at different spatial scales: a review, Catena, 23, 141-66, 1994.

Prokop, P. and Poręba, G. J.: Soil erosion associated with an upland farming system under population pressure in Northeast India, Land Degrad. Develop., 23, 310-321, 2012.

Robichaud, P. R., Lewis, S. A., Wagenbrenner, J. W., Ashmun, L. E., and Brown, R. E.: Post-fire mulching for runoff and erosion mitigation - Part I: Effectiveness at reducing hillslope erosion rates, Catena , 105, 75-92, 2013.

Romkens, M. J. M., Helming, K., and Prasad, S. N.: Soil erosion under different rainfall intensities, surface roughnessand soil water regimes, Catena , 46, 103-123, 2001.

Ruiz-Sinoga, J. D., Romero-Diaz, A., Ferre-Bueno, E., and Martínez-Murillo, J. F.: The role of soil surface conditions in regulating runoff and erosion processes on a metamorphic hillslope (southern Spain) soil surface conditions, runoff and erosion in southern Spain, Catena, 80, 131-139, 2010.

Ruy, S., Findeling, A., and Chadoeuf, J.: Effect of mulching techniques on plot scale runoff: FDTF modeling and sensitivity analysis, J. Hydrol., 326, 277-294, 2006.

Smets, T., Poesen, J., and Bochet, E.: Impact of plot length on the effectiveness of different soil-surface covers in reducing runoff and soil loss by water, Prog. Phys. Geogr., 32, 654-677, 2008a.

Smets, T., Poesen, J., and Knapen, A.: Spatial scale effects on the effectiveness of organic mulches in reducing soil erosion by water, Earth-Sci. Rev., 89, 1-12, 2008 b.

Zhao, G., Mu, X., Wen, Z., Wang, F., and Gao, P.: Soil erosion, conservation and Eco-environment changes in the Loess Plateau of China, Land Degrad. Develop., 24, 499-510, 2013. 